\title{
The sources and challenges of norm generation in tort law
}

\author{
Maria Lee*
}

\section{Introduction}

Courts in tort cases set standards of behaviour for society, often using common-sense sounding benchmarks such as 'reasonableness'. To do so, they need to 'know' things, sometimes controversial and difficult things, and are required to address multiple claims to knowledge and to attribute weight to them. Once we move into areas of high technical or scientific complexity, including risk regulation, questions are inevitably raised about the capacity and legitimacy of courts, using these general norms, to set standards.

In this article, I explore one of the ways in which courts have constructed norms of behaviour. I argue that courts use sources of authority from the world beyond tort to establish facts for the purpose of making a decision on appropriate tort standards. Facts, rather than being separate from and prior to the application of the legal norms, are often inseparably bound with legal judgment in any particular decision. In the process of adjudication, courts may confer enhanced authority on certain knowledge claims, contributing to the shaping of scientific facts, whilst these knowledge claims can simultaneously be a way to enhance the legitimacy of judicial fact finding and standard setting. ${ }^{1}$ Tort courts turn to a range of external sources for guidance, examining standards, rules and understandings from scientific bodies, regulators, legal documents, to shape the norms that are formulated and applied within tort. Categorising these approaches as 'external' may seem a little paradoxical, since one of the features I explore in this paper is precisely the difficulty of drawing clear lines between the internal and the external. fThe point is the way in which the debate about 'deference' to authoritative public decision making in public law reshapes itself in private law. This is a paper about tort law, not about public or administrative law, but public authorities and others are often active in the same space as tort, and may provide relevant, applicable or authoritative standards of behaviour. Tort

\footnotetext{
* University College London. I am grateful to the editors, and other participants at the Judge Made Risk Regulation Workshop, Utrecht 9-10 February 2017 for their very helpful comments on this paper. 1 Sheila Jasanoff's work on co-production is very useful here. See S Jasanoff (ed), States of Knowledge: The Co-Production of Science and Social Order (Routledge, 2004); Maria Weimer and Anniek de Ruijter (eds), Regulating Risks in the EU - The Co-production of Expert and Executive Power (Hart Publishing, forthcoming, 2017); Elizabeth Fisher, 'Climate Change Litigation, Obsession and Expertise: Reflecting on the Scholarly Response to Massachussets v EPA' (2013) 35 Law \& Policy 236.
} 
neither ignores public policy and applies autonomous, internal standards, nor defers to standards set by some external source, perhaps government standards. The response to standards set elsewhere is as central to tort as to public law. One of the implications of this paper is that the lines between private and public, and the questions raised by different areas of law, have much in common. Whether in public (more obviously risk regulatory) or private law litigation, we are often concerned with questions related to constitutional competence, where the argument would be that other (democratic) procedures are more appropriate ways of distributing benefits and burdens, and institutional competence, where the argument would be that other (expert) procedures are better able to reach a good decision. Those other bodies are often a legislative or a government body. But the cases go beyond a simple assertion that either the court or the government / legislature decides.

I examine two areas of tort law: some of the English asbestos cases; and perhaps inevitably, the Dutch Urgenda climate change case. ${ }^{2}$ Both involve questions of negligence or fault. The facts involved in the setting of and compliance with these standards of behaviour are the focus of this article, rather than the facts (so often central in the discussion of tort and risk), and problematic evidential issues, about causation. ${ }^{3} \mathrm{I}$ aim at both more and less than a discussion of 'fault' in negligence. Less, because there is much more at stake in that discussion: what constitutes 'fault' or the 'reasonable' raises all sort of practical and conceptual challenges, and is possibly underexamined, at least in English law. ${ }^{4}$ More, because a similar analysis may apply beyond negligence. Urgenda refers to 'open standards and concepts, including social [propriety], reasonableness and propriety, the general interest or certain legal principles'. ${ }^{5}$ Many equally open ideas could be found elsewhere in English law. To take one example of a non-fault based tort, private nuisance is a tort against landrelated rights, largely governed by the very flexible notion of 'reasonable use' of land. Planning permission is straightforwardly not a defence to private nuisance, but the more interesting question, raised by a number of important cases, ${ }^{6}$ is about the relevance of regulation, and other norms about land use, in shaping reasonable use.

\footnotetext{
${ }^{2}$ Urgenda Foundation $v$ The State of the Netherlands (Ministry of Infrastructure and the Environment 24 June 2015, English translation at https://uitspraken.rechtspraak.nl/inziendocument?id=ECLI:NL:RBDHA:2015:7196.

${ }^{3}$ So I am not writing about the line of case law arising out of Fairchild, but the more routine cases. Fairchild v Glenhaven Funeral Services Ltd [2003] 1 AC 32

4 But see eg John Gardner, 'The Negligence Standard: Political not Metaphysical' (2017) 80 Modern Law Review 1; Maria Lee, 'Safety, Regulation and Tort: Fault in Context' (2011) 74 Modern Law Review 555.

5 Para. 4.43

6 See the discussion in Maria Lee, 'The public interest in private nuisance: collectives and communities in tort' (2015) 74 Cambridge Law Journal 329.
} 
The asbestos cases are largely backward looking, revisiting the risk regulation of earlier decades; Urgenda is highly future oriented. Both sets of cases challenge, more or less directly and explicitly, the standards set by regulatory bodies, or the application of those standards by regulatory bodies, in one case retrospectively (without a direct defence by the regulatory body), in the other prospectively (with a hearty government defence). I claim no expertise in the broader Dutch context, and my mind is on English law as I develop my ideas. Moreover, I am conscious of the dangers in picking out a single, irresistible case from a foreign jurisdiction. But the Dutch case provides a striking illustration of the way in which courts sometimes rely on the knowledge claims of non-binding external actors. It is in any event difficult to generalise about standard setting within a single jurisdiction, or even a single English tort. And whilst that difficulty generalising makes firm conclusions elusive, it also emphasises the basic points made here, about the diversity and complexity of the construction of tort standards.

This article turns next to the asbestos cases and then to Urgenda. In part of course, the use of external norms raises questions of evidence, and the law of evidence, which are not my concern. Different jurisdictions have different rules and approaches to how evidence enters the courtroom, and there are often significant limitations on courts 'knowing' much more than what they learn from the parties before them. When I refer here to the 'court' knowing or doing something, that will often be because of the actions or knowledge claims of the parties, their legal representatives or their experts. The final section explores in more depth the various sources that these two lines of case law use to construct appropriate standards of behaviour, and the 'good enough' nature of the knowledge relied on.

\section{Asbestos}

Asbestos is a mineral with extraordinary properties. It is resistant to fire, chemicals and mechanical traction, and it can be spun into yarn and woven into cloth. As such it has been used widely, in industrial activities, as a fire break in buildings and ships, and in mechanical applications. Unfortunately, the health problems associated with asbestos are equally impressive. The dust from asbestos causes, among other things, lung disease, specifically asbestosis, mesothelioma, and lung cancer. The English litigation over illnesses caused by asbestos is fragmented, and has been heard over many years, raising different issues of law, and with different results. Its apogee has probably been in its extraordinary impact on 
the law of causation. ${ }^{7}$ Causation may speak directly to the responsibilities we owe to one another, and so the standards expected of each other, and the Fairchild saga tells us a great deal about the supposed immutability of the correlative nature of negligence. But I shall focus on more direct expressions of standards of behaviour towards employees and local communities exposed to asbestos, rather than on causation. I shall also focus on industrial activities rather than, for example, the presence of asbestos in buildings. ${ }^{8}$

I discuss here cases in the tort of negligence. ${ }^{9}$ The first question in the English law of negligence is whether the defendant owes the claimant a duty of care. An employer straightforwardly owes its employees a duty of care in respect of personal injury, but as discussed below, the requirement that a claimant's illness be reasonably foreseeable has raised questions about whether a duty is owed to other claimants, such as family members and those living around factories. Turning to whether that duty is breached, the conventional bar for standard setting in English negligence law is the 'reasonable person', sometimes coupled with a requirement for prudence or care: 'Negligence is the omission to do something which a reasonable man, guided upon those considerations which ordinarily regulate the conduct of human affairs, would do, or doing something which a prudent and reasonable man would not do'; ${ }^{10}$ negligence involves 'acting in a way in which someone would not have acted if they had taken reasonable care'. ${ }^{11}$ The reasonable person standard is in principle open to all sorts of considerations from external criteria, ${ }^{12}$ so I am not by any means suggesting that the asbestos cases are unique. The English courts balance a range of factors 'intuitively, qualitatively, verbally, impressionistically, and on the basis of their largely tacit assessments of what is fair and socially valuable'. ${ }^{13}$ The factors balanced depend on the circumstances, but include foreseeability of harm, likelihood of harm, gravity of harm, and the cost of precautions.

\footnotetext{
7 See Fairchild, supra, note3; and for an odd (Lord Hoffmann was prominent in Fairchild and subsequent cases) but revealing glimpse of the backlash, Lord Hoffmann, 'Fairchild and After' in Burrows, Johnston and Zimmermann (eds), Judge and Jurist: Essays in Memory of Lord Rodger of Earlsferry (2013). But this is not considered in this paper.

${ }^{8}$ Eg Michael Lees, 'Asbestos in Schools' (2016) Journal of Personal Injury Law 1.

9 The tort of breach of statutory duty has also been important, including in settlements, see eg Nick Wikeley, 'Turner \& Newall: Early Organizational Responses to Litigation Risk' (1997) 24 JLS 252; Margereson and Hancock $v$ JW Roberts [1996] PIQR 154 (High Court), p. 171. See also the decision on the first defendant in Jeromson $v$ Shell Tankers UK Ltd; Dawson $v$ The Cherry Tree Machine Co Ltd [2001] EWCA Civ 101; [2001] PIQR 19, discussed below. But on the demise of breach of statutory duty in the future, see now the Enterprise and Regulatory Reform Act 2013.

10 Blythe v Birmingham (1856) 11 Ex 781, Alderson B, p. 784.

11 John Gardner, 'The Many Faces of the Reasonable Person' (2015) Law Quarterly Review 563 brings out the extreme openness of this standard.

12 See Gardner's discussion of the fundamental conceptual ambiguity around the openness, ibid.

${ }^{13}$ Stephen G Gilles, 'The Emergence of Cost-benefit Balancing in English Negligence Law' (2002) 77 Chicago-Kent Law Review 1, p. 8.
} 
The Asbestos Industry Regulations 1931 were notoriously inadequate. The asbestos industry itself was very closely involved in their development, whilst the trade unions were late in the day presented with a more or less complete draft by government. ${ }^{14}$ The regulations stayed in place unamended until 1969. ${ }^{15}$ And notwithstanding their substantive weaknesses, the regulations were in any event poorly enforced. Regulators, industry and trade unions all seemed to have accepted a low level of compliance, in the interests of economic growth. ${ }^{16}$ Although the regulations were routinely breached, there were only two prosecutions between 1931 and $1968 .{ }^{17}$ Such a failure to comply with regulation is, in English tort law, not in principle decisive of negligence, ${ }^{18}$ although breach of statutory standards is non-conclusive evidence of breach in negligence, ${ }^{19}$ and legality is one of the range of issues relevant to deciding what a reasonable person would do in any particular case. ${ }^{20}$ Many of the asbestos cases involve statements along the lines that defendants 'made no serious effort to conform' with their statutory obligations, ${ }^{21}$ and indicate tort's capacity to step in when official enforcement is weak. In many asbestos cases, the employer's fault is egregious and there is little detailed work for the common law to do in terms of standard setting.

The different aetiologies and understandings of two of the lung diseases caused by asbestos have been legally significant. Asbestosis was recognised many decades earlier than mesothelioma. Asbestosis is caused by heavy, prolonged exposure to asbestos, and was the focus of the 1931 Regulations, which concentrated on the dustiest industries. Mesothelioma, by contrast, can be caused by light and occasional exposure (although the greater the exposure, the greater the risk), and was unknown to science or medicine until decades later. In the case of Margereson, the claimants, who when children had lived and played around the defendant's factory, sued the defendants in respect of the mesothelioma they suffered many decades later. ${ }^{22}$ The Court of Appeal held that the reasonable foreseeability of 'some pulmonary injury' is sufficient to establish that the claimant's harm is

\footnotetext{
${ }^{14}$ Notwithstanding some efforts by government to engage the TUC, see Nick Wikeley, 'The Asbestos Regulations 1931: A Licence to Kill?' (1992) 19 Journal of Law and Society 365.

${ }^{15}$ Although even in 1931 the Chief Inspector of factories described the 'dust datum' (discussed below) as 'clearly provisional', see Wikeley, ibid., p. 368.

16 Wikeley, ibid.

17 European Environment Agency, Late Lessons from Early Warnings: The Precautionary Principle 1896-2000 (EEA, 2002), p. 56.

${ }^{18}$ It was once a staple of breach of statutory duty, supra, note 9.

19 Glanville Williams, 'The Effect of Penal Legislation in the Law of Tort' (1960) 23 Modern Law Review 233; Blamires v Lancs and Yorks Ry (1873) LR 8 Ex 283.

${ }^{20}$ Eg Overseas Tankship (UK) Ltd $v$ The Miller Steamship Company (The Wagon Mound) (No 2) [1967] 1 AC 617 (PC), p. 643, Lord Reid.

${ }^{21}$ For example, Margereson and Hancock $v$ JW Roberts [1996] PIQR 154 (High Court), p. 167.

22 [1996] Env LR 304 (CA).
} 
reasonably foreseeable for the purposes of duty of care, meaning that scientific and medical ignorance of the disease of mesothelioma was not immediately fatal to a claim in negligence.

In Jeromson, ${ }^{23}$ liability was imposed on the employers of claimants who had contracted mesothelioma working in ship building and repair in the 1950s, before the disease of mesothelioma had even been recognised. Margereson, as mentioned above, meant that claims could in principle be brought for mesothelioma contracted before scientists had recognised the disease. In Jeromson, the question remained whether the reasonable person would have taken precautions in respect of less heavy and less frequent exposure. The Court considered the weighty Merewether and Price report, a publication of the British government in 1930, ${ }^{24}$ and the Asbestos Industry Regulations 1931 (although they did not apply to the claimant), both of which focused on asbestosis. The judgment also discussed the Factories Act 1937 and the Reports of the Chief Inspector of Factories. This material indicated the dangers associated with dust generally, and with asbestos specifically, if not necessarily directly with the activities carried on by the claimant, specifically stripping asbestos insulation and replacing it. Advice to the ship building and repair industry and to power stations, whilst not in all respects applicable to the claimants, was said to identify the 'thinking' of the Factories Inspectorate. ${ }^{25}$ The 'prudent employer' would have taken precautions, or in the first instance have made inquiries about precautions.

In the two cases of Margereson and Maguire, by contrast with Jeromson, the claimants were not employed by the defendants. The defendants were clearly in breach of the duties they owed to their employees, but the question was their position with respect to non-employees. Mrs Maguire sued her husband's employer, having contracted mesothelioma as a result of exposure to asbestos when washing her husband's work clothes. She was unsuccessful. The Court of Appeal focused inconsistently on the position of the claimant (a family member exposed in the home) and the type of exposure (lighter and more intermittent than that associated with asbestosis ${ }^{26}$ ) and also elided consideration of the existence and the breach of the duty of care. ${ }^{27}$ The Court concluded that the way in which Mrs Maguire was harmed would not have been reasonably foreseeable until late 1965 , by which time her husband no longer worked for the defendants. In reaching that conclusion, the Court turned to regulatory and specialist literature, noting the absence of any warnings with respect to familial exposure

\footnotetext{
${ }^{23}$ Supra, note 9.

${ }^{24}$ Report on effects of asbestos dust on the lungs and dust suppression in the asbestos industry (HMSO, 1930).

25 Para. 42.

${ }^{26}$ Maguire $v$ Harland and Wolff Plc [2005] EWCA Civ 01, [2005] PIQR 21, eg [48], [56-57]. See also Rice $v$ Secretary of State for the DBERR [2008] EWHC 3216 (QB).

27 See para. 62.
} 
in 'the specialist safety, medical or factory inspectorate literature'. ${ }^{28}$ The 'numbing silence'29 on the matter was only broken in late 1965, when two articles appeared in the specialist literature, subsequently reported in the Sunday Times.

In Margereson, outlined above, whilst it was clear that the defendant's efforts 'to alleviate the problems of dust contamination were woefully inadequate', ${ }^{30}$ the Court had to consider whether it owed a duty of care in respect of environmental exposure to asbestos around the defendant's factory. The Court of Appeal concluded that 'the information which should have operated upon the defendant's corporate mind' in respect of the ability of asbestos dust to cause pulmonary injury was 'in existence long before Mr Margereson's birth date', which was in 1925. This predates not only understanding of mesothelioma, but also the Merewether and Price report, conventionally identified as the earliest official interest in asbestos, and regulation directed at asbestosis. The reasonable foreseeability that underpinned the industry's duty to local residents was based on various early factory inspectorate reports, as well as the workplace regulation of dust generally from the $19^{\text {th }}$ century onwards. ${ }^{31}$ The important difference between Margereson and Maguire may be the quantity of exposure in the former, which was similar to that experienced within the 'factory walls'. ${ }^{32}$

\section{Climate Change}

Urgenda is a famous case in which a Dutch NGO (Urgenda) brought a successful action in 'hazardous negligence' against the Dutch government's climate change policy. ${ }^{33}$ The Netherlands had set its greenhouse gas emissions reduction target at $17 \%$ by 2020 against a 1990 baseline, in accordance with the overall EU target of a $20 \%$ reduction by $2020 .{ }^{34}$ The Court ordered the Netherlands to take action to cut its climate change emissions by $25 \%$. The decision is controversial on a range of measures, including standing, separation of

\footnotetext{
28 Para. 21.

29 Para. 57.

30 Margereson, supra, note 22, p. 307.

${ }^{31}$ See especially the High Court decision, pp. 175-76.

32 But note the different approach of Maguire and Jeromson. In Maguire, the silence lets the defendant off the hook, in Jeromson, the emphasis is on a general understanding that asbestos is dangerous, and the silence on the existence of any safe level places responsibility on the defendant to take precautions or seek advice.

${ }^{33}$ Supra, note 2.

${ }^{34}$ On the tricky interaction with EU law, see Suryapratim Roy and Edwin Woerdman, 'Situating Urgenda versus the Netherlands within Comparative Climate Change law' Journal of Energy and Natural Resources Law 165.
} 
powers (or balance of powers) and causation, ${ }^{35}$ and not all are confident about Urgenda's chances in the appeal. ${ }^{36}$ The decision could even have been overturned by the time this paper is published. But I am interested particularly in the question of judicial methodology, the way in which the Court constructed the standard of care in this case, ${ }^{37}$ regardless of the way in which the actual decision is ultimately resolved.

Urgenda is a striking case of the courts borrowing the epistemic authority of external norms. The Court is quite explicit about its lack of independent expertise, and refers to its reliance on 'current scientific knowledge and (other) data the State [ie the defendant] acknowledges or deems to be correct'. ${ }^{38}$ Section 2 of the judgment discusses a range of international, EU and domestic scientific, policy and legal material, quoting at considerable length from a number of documents. It quotes, for example, the Intergovernmental Panel on Climate Change (IPCC), an organisation set up by the World Meteorological Organisation and the United Nations Environment Programme and described by the Court as 'a global knowledge institute'. ${ }^{39}$ It runs through the UN treaty framework and several COP (conference of the parties) decisions, as well as EU policy and law and Dutch scientific and policy documents. This lengthy part of the judgment seems simply to provide some context and background on the climate change problem. It is headed 'the facts' in English, and the decision making part of the judgment constantly refers back to it.

The Court relies heavily on IPCC reports, and their acknowledgement by others, including the COP. Both parties also accepted the authority of the IPCC reports; the Dutch government had done so in other contexts and presumably had no wish to reverse that position, and Urgenda based much of its claim on the IPCC reports. The Court's review of the impacts of climate change lead it to the 'intermediate conclusion' that:

'Anthropogenic greenhouse gas emissions are causing climate change. A highly hazardous situation for man and the environment will occur with a temperature rise of over $2^{\circ} \mathrm{C}$ compared to the pre-industrial level. It is therefore necessary to stabilise the

\footnotetext{
35 For a broader discussion of the case, see the notes cited herein, plus Jolene Lin, 'The First Successful Climate Negligence Case' (2015) 5 Climate Law 65; Josephine van Zeben, 'Establishing a governmental Duty of Care for Climate Change Mitigation: Will Urgenda Turn the Tide?' (2015) 4 Transnational Environmental Law 339.

${ }^{36}$ KJ Graaf and JH Jans, 'The Urgenda decision: Netherlands Liable for Role in Causing Dangerous Global Climate Change' (2015) 27 Journal of Environmental Law 517; Lucas Bergkamp, 'The Urgenda judgment: a "victory" for the climate that is likely to backfire' http://energypost.eu/urgendajudgment-victory-climate-likely-backfire/.

${ }^{37}$ The application of ordinary negligence in this case may be an important factor in the appeal.

38 Para. 4.3.

39 Para. 4.12.
} 
concentration of greenhouse gases in the atmosphere, which requires a reduction of the current anthropogenic greenhouse gas emissions. ${ }^{\prime 40}$

Turning to the concentration of carbon dioxide equivalent in the atmosphere, discussed further below, 'the court concludes that in view of risk management and from scientific considerations, there is a strong preference for the 450 scenario, as the risks are much higher with a 500 scenario. ${ }^{41}$ Referring to earlier discussions of the IPCC, EU policy, the endorsement by Annex I countries of the necessity of $25-40 \%$ reductions in Cancun, the Netherlands' earlier policy of a $30 \%$ reduction by 2020 , the Court reaches a

'further intermediate conclusion that according to the current scientific position, the prevention of dangerous climate change calls for a 450 scenario with an associated reduction target for the Annex I countries, which includes the Netherlands and the EU as a whole, of $25-40 \%$ in 2020 , and $80-95 \%$ in $2050 .{ }^{4}$

From here,

'It is an established fact that with the current emission reduction policy of $20 \%$ at most in an EU context (about 17\% in the Netherlands) for the year 2020, the State does not meet the standard which according to the latest scientific knowledge and in the international climate policy is required for Annex I countries to meet the $2^{\circ} \mathrm{C}$ target. ${ }^{43}$

The Court concludes that a $25 \%$ reduction 'is the absolute minimum and sufficiently effective, for the Netherlands, to avert the danger of hazardous climate change'. ${ }^{4}$

The breach of international legal obligations in this case explicitly did not constitute a legal wrong against Urgenda, ${ }^{45}$ and the same must apply to the other non-binding sources referred to here, be they IPCC or EU documents. Rather, in what the Court called a 'reflex effect', these materials contributed to the shaping of the civil law standard of care. ${ }^{46}$ Whilst the Netherlands enjoys a broad discretion in the area of climate change, 'the objectives and principles, such as those laid down in the UN climate change convention and the TFEU [Treaty on the Functioning of the European Union], should also be considered in determining the scope for policymaking and duty of care'. ${ }^{47}$

\footnotetext{
40 Para. 4.18.

41 Para. 4.22.

42 Para. 4.29.

43 Para. 4.84.

44 Para. 4.86.

45 Para. 4.42.

46 Para. 4.42, also on the EU, para. 4.43 .

47 Para. 4.54.
} 
The Court takes international scientific, policy and legal documents, supported by EU and domestic material, to take the parties inexorably, step by step, to the conclusion that the Netherlands is in breach of its duty. These conclusions are presented as fact, incontrovertible and inevitable. In part of course this is because in Dutch procedural law, once the parties agree on the facts, those facts enter the decision making process. But equally, the parties disagree most vehemently on the outcome, the appropriate approach to climate change, and the outcome is an inextricable combination of legal judgment with these facts as presented by (and to) the Court.

\section{How courts know ${ }^{48}$}

The sources of knowledge considered in the cases are diverse and gain their authority in very different ways. Some are simply binding legal documents, for example the Asbestos Industry Regulations 1931, at least when applied to the activities subject to their terms. Some are non-binding 'regulation', for example when those Regulations are used to provide context in respect of other industries, or some of the COP undertakings relied on in Urgenda. Some are 'governmental', regulator's reports, codes of practice, consultation papers, or superseded policies. We have international and domestic 'scientific' bodies, such as the IPCC and the Royal Netherlands Meteorological Institute (KNMI), and from a different era the Merewether and Price report, as well as academic and popular articles.

Elsewhere I have said that external norms like these make both a pragmatic and an epistemic contribution to tort. ${ }^{49}$ Pragmatically for example, they allow courts to sidestep difficult questions of evolving behaviour, clarifying the information available to the reasonable person at the relevant time. The broad literature assists the court with establishing what the defendant knew or ought to have known, and might outline responses that are considered feasible in the broader community. I am more interested here in the epistemic role of external norms. Straightforwardly, they allow the courts to 'know'. The courts 'must provide an authoritative understanding of the factual matrix', but they do not find the facts independently, or solely on the basis of expert reports, ${ }^{50}$ instead 'weaving into [their] account how other institutions have found facts. ${ }^{51}$ We are quite used to the idea that courts explicitly and implicitly provide criteria for the conduct of public standard setting, and even for the

48 I borrow the heading from Austin Sarat, Lawrence Douglas, Martha Merrill Umphrey (eds), How Law Knows (Stanford University Press, 2007).

${ }^{49}$ Supra, note 3.

${ }^{50}$ Although that might be the way in which this broader material enters the court room.

51 Fisher supra, note 1, p. 251 
adequacy of scientific evidence in policy contexts. The courts' approval or adoption of external norms and standards confers a certain authority and legitimacy on those standards. Here we also see the other side of this, as those norms simultaneously confer authority on the fact finding and standard setting of the courts. ${ }^{52}$ The courts are empowered to look more confidently beyond the claims of the defendant, when the defendant (including a state defendant) is claiming some specialist expertise: that the Dutch state knows best what action should be taken on climate change; that the asbestos industry (and government regulators) knew best how to balance economic and safety demands. These external sources provide the courts with a certain epistemic legitimacy. ${ }^{53}$ And again, as well as reinforcing the epistemic authority of courts, this approach may also reinforce the authority of the facts and external fact finders.

But this is not simply a fact finding exercise. The presentational approach of the court in Urgenda, with multiple references to facts and established facts, ${ }^{54}$ whilst perhaps a normal effect of Dutch legal procedure, is important. The asbestos cases also present their facts as very straightforward and unexciting. In Margereson for example, the Court of Appeal presents the first instance judge's findings as 'essentially findings of fact', and its own conclusions as depending upon 'elementary legal principles', notwithstanding considerable legal innovation. ${ }^{55}$ This emphasis on stability, and on a rhetorically straightforward integration of any judgment into what precedes it, is an important part of legal reasoning. ${ }^{56}$ But it is worth observing that these are not simple facts, they are highly normative. To say that a reasonable person would have behaved differently from the ways in which the defendant's predecessors in the early to mid-twentieth century behaved, is anything but a simple factual statement, even if deemed a question of fact not law. ${ }^{57}$ In Urgenda we have not just findings of fact (about climate change), but an inextricable combination of fact and legal conclusion. Sometimes the normative choices made by the courts are clear on the face of the decision: 'the court concludes that in view of risk management and from scientific considerations, there is a strong preference for the 450 scenario, as the risks are much

\footnotetext{
52 Supra, note 1.

${ }^{53}$ Medical negligence cases are also revealing. Rather than simply deferring (or deciding between) experts put forward by the parties, the courts can refer to guidelines are produced by, for example, the Royal Colleges, societies such as the British Society of Dermatology, pharmaceutical companies, and the National Institute for Health and Clinical Excellence, part of the NHS. See A. Samanta et al, 'The Role of Clinical Guidelines in Medical Negligence Litigation: A Shift from the Bolam Standard?' (2006) 14 Medical Law Review 321; Ministry of Justice v Carter [2010] EWCA Civ 604.

54 Para. 4.65; also eg para. 4.84.

55 Jenny Steele and Nick Wikeley, 'Dust on the Streets and Liability for Environmental Cancers' (1997) 60 Modern Law Review 265.

56 See eg Elizabeth Fisher, Eloise Scotford and Emily Barritt, 'The Legally Disruptive Nature of Climate Change' (2017) 80 Modern Law Review 173.

${ }^{57}$ Also Gardner supra, note 4 on fact and law in the 'reasonable person'.
} 
higher with a 500 scenario'; ${ }^{58}$ the judge at first instance in Margereson acknowledges that the problem is not 'any serious factual issue', but 'one of evaluation, that is of assessment, balance and judgment. ${ }^{59}$ More often, this remains, understandably, unspoken.

Many of the findings of fact relied on in the asbestos cases and Urgenda are not particularly socially contentious (or contentious between the parties), even if the legal implications may be, and the science is more complicated than is acknowledged. Some will of course disagree even here, and there will be more difficult cases where the facts are more profoundly contested, or are obviously unhelpful to resolving the value divide underlying the legal dispute. It might then be argued that the courts (and litigants) are cherry picking sources, and calling on the 'wrong' source. But the challenge is more interesting than whether the courts get it right or wrong. Apart from anything else, when knowledge claims are in abundance, all uses of that knowledge are somewhat selective. ${ }^{60}$ The knowledge used in these cases is complex, uncertain and socially constructed.

Starting with Urgenda, 'dangerous' climate change is interpreted by the court as a $2^{\circ} \mathrm{C}$ change in global temperature from pre-industrial levels. ${ }^{61}$ The impact of the concentration of carbon in the atmosphere on temperature is used to calculate a concentration target, the maximum amount of carbon dioxide-equivalent in the atmosphere; the IPCC reports (and various other national and international reports) assess the likelihood of meeting the $2^{\circ} \mathrm{C}$ target at different levels of carbon in the atmosphere - the risk of missing the target. The court is consistent with European policy in selecting 450 parts per million (ppm), compared to around $273 \mathrm{ppm}$ before the industrial revolution, as the appropriate target. And then this concentration of carbon is converted further into the long term emissions reduction targets that get all of the headlines, without generally referring back to the cumulative emissions that matter $^{62}$ Although there is a high level of scientific consensus, there are multiple uncertainties at each stage. ${ }^{63}$

'The court - and also the Parties - ... considers [the reports of the IPCC] as facts'. ${ }^{64}$ This turn to international orthodoxy is an important part of the search for socially and legally

\footnotetext{
58 Para. 4.22.

59 P. 158. See also Mance LJ's dissenting judgment in Maguire.

60 Daniel Sarewitz, 'How Science Makes Environmental Controversy Worse' (2004) 7 Environmental Science and Policy 385.

61 Para. 4.14.

62 Kevin Anderson and Alice Bows, "Beyond "Dangerous" Climate Change: Emission Scenarios for a New World' (2011) 309 Philosophical Transactions of the Royal Society A 20.

63 Naomi Oreskes, 'Science and Public Policy: What's Proof Got to Do With It?' (2004) 7 Environmental Science \& Policy 369.

64 Para. 4.12.
} 
acceptable decisions. Notwithstanding close scrutiny and severe attacks by those denying the existence, anthropogenic nature or urgency of climate change, the IPCC is a robustly influential institution, composed of hundreds of scientists, from all regions and representing developing and developed countries. ${ }^{65}$ It is a scientific, but explicitly 'policy relevant', body, whose reports are subject to endorsement by IPCC member governments. Its consensus driven, policy sensitive approach is generally thought to be likely to lead to conservative conclusions, so that our knowledge on climate change becomes a 'socially constructed understatement'. ${ }^{66}$ This is not because the science lacks integrity, and of course the scientists and many policy makers understand the complexity, but because of the inevitable social commitments of any science, in this case a mammoth project of science for global policy. It is hardly a criticism of Urgenda to say that it is out of date given the reference in the Paris Agreement to a $1.5^{\circ} \mathrm{C}$ temperature increase. ${ }^{67}$ But it is worth noting that both the adequacy and the feasibility of the $2^{\circ}$ target was already contentious: ${ }^{68}$ dangerous for whom, for what, with what level of confidence? Before even thinking about the uncertainties surrounding its achievement or its effects.

My point is not that Urgenda got it wrong and should have been bolder, or that the Court should have upended Dutch law by going beyond agreements between the parties. My point is that the court in Urgenda got it 'right enough' in a particular manner, reflecting but not opening up choices made in other fora. Whilst the legally controversial nature of Urgenda has been much remarked upon, it could be described (by anyone but a lawyer?) as a deeply conservative decision. Only $2^{\circ}$ ? That was always contentious. As much as 450 ppm? That leaves considerable risk of exceeding a $2^{\circ} \mathrm{C}$ global temperature increase. Only a $25 \%$ reduction target? Urgenda asked for $40 \%$, and the Court explicitly (understandably) chose the 'absolute minimum' level of mitigation. Moreover, it is clear from the judgment that it would have been open to the Dutch government to argue that the new standard should not be applied, for example because of cost implications. ${ }^{69}$ The court is hardly embracing the existential nature of the climate change risk.

\footnotetext{
65 On which see CA Miller, 'Climate Science and the Making of a Global Political Order' in Jasanoff supra, note 1.

${ }^{66}$ Brian Wynne 'Strange Weather, Again: Climate Science as Political Art' (2010) 27 Theory, Culture \& Society 289, p. 295.

67 'This Agreement ... aims to strengthen the global response to the threat of climate change ... including by: (a) Holding the increase in the global average temperature to well below $2^{\circ} \mathrm{C}$ above preindustrial levels and pursuing efforts to limit the temperature increase to $1.5^{\circ} \mathrm{C} \ldots$.

${ }^{68} \mathrm{Eg}$ Anderson and Bows, supra, note 62.

69 Paras. 4.77, 4.86.
} 
The asbestos cases are very different, but we see a similar tendency to the 'official' and to simplification. There is nothing like the IPCC, but 'official' voices, factories inspectors and government reports, are preferred. ${ }^{70}$ The cases all suggest a story of steadily and inexorably improving knowledge, ignoring the lone voices, the contests, and the to-ing and fro-ing that would have been more apparent in the moment. ${ }^{71}$ The cases discussed above do not address the question directly, but with decades of hindsight, they are able to move the reasonable person beyond one of the mostresonant 'socially constructed understatements' of asbestos regulation. The level of exposure of workers who did not swiftly develop asbestosis was considered the 'dust datum' by Merewether and Price, above which dust suppression measures should be taken; this was not supposed to be considered a safe level, ${ }^{72}$ but for reasons of practicality and convenience, it often was. ${ }^{73}$ The courts in cases some decades later were able to pick up on the reversal of the orthodoxy. Again, the point is not that the Courts can necessarily fix historical problems with the benefit of hindsight, but to observe how the courts get the facts 'right enough'.

Jasanoff talks about the difference between 'truth pure and simple', and 'serviceable truth"', which simply needs to be robust enough to allow decisions to go forward. ${ }^{74}$ Because of the high level of consensus, and the familiar sources used, this question of 'truth' is not on the surface of the decisions discussed above. The 'serviceability' of the truths being offered are nevertheless a significant part of the decision; the external sources and the courts together create a sufficiently robust knowledge for the court to go forward. What constitutes sufficiently robust knowledge will vary according to context, and is itself constructed within the process of decision making. The social and the legal are produced alongside the production of the facts, each shaping the other, and each reinforcing the other's authority. ${ }^{75}$

I have argued elsewhere that the authority of external norms within tort might vary according to their authority externally, ${ }^{76}$ and that one of the ways in which this might be considered is process: did the decision maker address the relevant material, did it have the relevant skills and expertise, did it consult appropriately? That would clearly not resolve all of our difficulties

\footnotetext{
70 Note again the historical nature of the discussion. In more contemporary cases, reflecting the greater fragmentation of 'regulation' / 'governance', the courts are also turning to private standards, see Lee supra, note 4.

71 Supra, note 17.

72 See also Hale LJ in Jeromson, para. 45.

${ }^{73}$ Wikeley supra, note 14.

74 Sheila Jasanoff, 'Serviceable Truths: Science for Action in Law and Policy' (2015) 93 Texas Law Review 1723, p. 1725.

${ }^{75}$ Supra, note 1.

76 Supra, note 4; 'Nuisance and Regulation in the Court of Appeal' (2013) Journal of Planning and Environmental Law 277.
} 
with the reliance on external sources. ${ }^{77}$ And I have also argued that courts are sometimes inadequately curious about the qualities of the external norms that they rely on: asserting the importance of a superior capacity for cost benefit analysis without examining the actual $\mathrm{CBA}^{78}$; asserting the superior democratic credentials of another decision maker without examining the actual process followed by that decision maker ${ }^{79}$; asserting the public benefit of an activity without examining the publicness of that activity. ${ }^{80}$ So I do not mean to suggest that the phenomenon I am discussing here is necessarily straightforward. Moreover, sometimes the distinction between deferring to external norms and their pragmatic but nonhierarchical use will be a fine one. ${ }^{81}$ But it is nonetheless important. The courts neither hand over their authority to external sources, nor ignore the authority and relevance of those sources. And to complain that the courts identify satisfactorily robust evidence in an unsatisfyingly ad hoc way does not dramatically distinguish the courts from others, including the disciplines of science themselves, where 'robust consensus' may be constituted in very different ways according to the subject area and the social commitments and contexts surrounding it. ${ }^{82}$

\section{Conclusions}

The courts in these cases call on diverse sources to construct their ideas of negligence and reasonableness, to set standards in tort. The two sets of cases challenge regulatory standard setting, one retrospectively and one prospectively. They also speak to quite different ways of knowing. Climate science is not intuitive, it 'cuts against the grain of common sense' and 'detaches knowledge from meaning', when that meaning comes from lived experience. ${ }^{83}$ But the courts take the globalised and abstract knowledge presented to construct their own legal standards. Asbestos is quite different, in that the courts are faced with the dead and the dying, and the descriptive reconstruction of industrial behaviour fits into a narrative of linearly developing knowledge, reluctant employers, and victims without

\footnotetext{
77 I have not raised all of the dilemmas, of course. The costs to gathering and organising all of this information must be acknowledged, as must the real skill in the knowledge generation in the cases discussed here.

78 'Occupying the Field: Tort and the Pre-Emptive Statute', in J Steele and TT Arvind (eds), Tort Law and the Legislature (Hart Publishing, 2012).

79 'Hunter v Canary Wharf in Paul Mitchell and Charles Mitchell (eds), Landmark Cases in the Law of Tort (Hart Publishing, 2010).

80 Supra, note 5.

${ }^{81}$ See Graaf and Jans supra, note 14 on whether Urgenda renders meaningless the provisions of the Dutch constitution limiting the rights for individuals in international law.

82 Oreskes, supra, note 63.

${ }^{83}$ Sheila Jasanoff, 'A New Climate for Society' (2010) 27 Theory, Culture and Society 233.
} 
choices. A sequence has been reconstructed in the cases, and the courts set retrospective standards of action that reasonable people would have taken.

The malleability of open ended, rhetorically fact based, standards like the reasonable person can be a significant advantage. ${ }^{84}$ The approach of the courts to external norms means that the courts maintain their own authority and responsibility to set standards, but are able also to acknowledge and rely on the authority of other actors. The polarisation of either ignoring or deferring to 'expertise' or democratic authority, is inadequately sensitive to this: the cases both challenge the aspirations of official policy, and rely on more or less 'official' material to construct the content of a duty. But this probably necessary process is extraordinarily complicated, and potentially problematic. The intention of the previous section was not to criticise the approach of the courts, simply to outline some of the complexity of even authoritative knowledge, and to attend to the ways in which legal standards and scientific or technical knowledge are mutually constitutive.

${ }^{84}$ Gardner, supra, note 4. 